\title{
Beyond the freedom to build: Long-term outcomes of Elemental's incremental housing in Quinta Monroy
}

\author{
Além da liberdade de construção: resultados de longo \\ prazo da moradia incremental da Elemental na Quinta \\ Monroy
}

Sandra Carrasco [a,b] [D], David O'Brien [a] [D

\begin{abstract}
[a] Faculty of Architecture, Building and Planning, University of Melbourne, Melbourne, Australia
[b] School of Architecture and Built Environment, University of Newcastle, Newcastle, Australia
\end{abstract}

How to cite: Carrasco, S., \& O'Brien, D. (2021). Beyond the freedom to build: Long-term outcomes of Elemental's incremental housing in Quinta Monroy. urbe. Revista Brasileira de Gestão Urbana, v. 13, e20200001.

https://doi.org/10.1590/2175-3369.013.e20200001

\section{Abstract}

In 2003, the Chilean architecture firm Elemental began to revisit the idea of partially completed housing harnessing the productive capacities of the informal process within a more formal framework. The Quinta Monroy project in the northern Chilean city of Iquique was the first such project and involved the in-situ replacement of an informal settlement. The desire of residents was for a middle-class house that was beyond the scope of their budget or the subsidy. The Elemental project at Quinta Monroy comprised 93 expandable houses designed in parallel buildings and organized in four courtyards aiming to promote community interaction and maintain neighbors' affinities. This paper investigates the process of housing adaptation through self-construction twelve years after the residents received their homes in 2005. The strategy to promote resident-driven expansions has been successful as 92 out of 93 households expanded their homes. The most significant concerns focused on the deterioration of living standards due to progressive and uncontrollable extensions which might have significant impacts on the settlement development. The findings from this paper focus on the neighbors' negotiations for housing extensions and the risk of the re-creation of precarious living environments evidencing limitations for unassisted or spontaneous incremental schemes of housing development.

Keywords: Quinta Monroy. Elemental. Incremental housing. Iquique, Chile.

\section{Resumo}

Em 2003, o escritório de arquitetura chileno Elemental começou a revisitar a ideia de moradias parcialmente concluídas, aproveitando as capacidades produtivas do processo informal dentro de uma estrutura mais formal. $O$ projeto Quinta Monroy, na cidade chilena de Iquique, no norte, foi o primeiro a ser implantado e envolveu a

\footnotetext{
SC is architect, PhD in Environmental Management, postdoctoral researcher, e-mail: sandra.carrasco@unimelb.edu.au / sandramcarrasco1@gmail.com DO is architect, PhD in Architecture, senior lecturer, e-mail: djobrien@unimelb.edu.au
} 
substituição in situ de um assentamento informal. o desejo dos moradores era de uma casa de classe média, o que estava além de seu orçamento ou capacidade financeira. O projeto Elemental na Quinta Monroy compreendeu 93 casas expansíveis, projetadas em edifícios paralelos e organizadas em quatro pátios com o objetivo de promover a interação da comunidade e a sociabilidade entre vizinhos. Este artigo investiga o processo de adaptação por meio da autoexpansão de moradias doze anos após os moradores receberem suas casas em 2005. A estratégia para promover expansões dirigidas por residentes foi bem-sucedida considerando-se que 92 de 93 famílias expandiram suas casas. As preocupações mais significativas se concentraram na deterioração dos padrões de vida devido a extensões progressivas e incontroláveis que podem ter impactos significativos no desenvolvimento do assentamento. As conclusões deste artigo concentram-se nas negociações dos vizinhos sobre extensões habitacionais e no risco de recriação de ambientes precários, evidenciando limitações para esquemas incrementais não assistidos ou espontâneos de desenvolvimento habitacional.

Palavras-chave: Quinta Monroy. Elemental. Habitação incremental. Iquique, Chile.

\section{Introduction}

Adequate housing is a globally recognized human right, a basic need and an indicator of adequate standard of living stated in the new urban agenda (UN-Habitat, 2016). A desired and valuable commodity that is elusive for the $48 \%$ of the urban population in developing nations (UN-Desa, 2014). Countries in Latin America were the first in the global south to experience a process of rapid urbanization which produced sharp contrasts and economic disparities. Housing policies in Latin America were unable to encompass the immense housing pressures poorly targeting the lowest income groups evidenced in about $20 \%$ of the population still living in slums (World Bank, 2014). This explaining how informal and progressive housing construction became the defacto urban growth pattern for the poor (Goethert, 2010).

Latin America is considered the birthplace of moves validating self-help housing since the second half of the twentieth century (UN Habitat, 2011). Housing policies were also influenced by Turner's seminal research legitimizing peoples' freedom to manage their resources while achieving their desired living environments (Turner \& Fichter, 1972). Latin American governments implemented schemes of incremental housing with multiple variations including a basic housing unit. These units became the starting point of subsequent extensions following a pay-as-you-go format (Goethert, 2010) according to the financial capacities of the poor.

Chilean housing programs incorporated incremental strategies since early 1950s which particularly targeted slums. Interestingly, the housing programs aiming to eradicate the country's slums were also the origin of self-help housing approaches (Arriagada et al., 2004). Later housing programs moved away from providing fully-built houses in favor of granting housing subsidies for new houses and enabling different types of housing improvements and extensions. In early 2000s, the program 'Chile Barrio' (Chilean Neighborhood) aimed to incorporate diverse stakeholders to create innovative housing projects for the poor (Arriagada et al., 2004) together with resident-driven incremental housing programs such as the Dynamic Social Housing Without Debt.

In this context, innovative and experimental projects emerged, among them the project of Quinta Monroy designed by the Chilean award-winning architecture firm Elemental. Quinta Monroy is an onsite slum upgrading housing project which combined innovation in the housing design, and use of the reduced land and financial resources available (Aravena, 2014; Arriagada et al., 2004). Elemental's design offers an alternative perspective for addressing the housing deficit for the poor and building a 'half good house' (Aravena, 2014) providing a partly infilled structural framework that can support resident-built extensions that complete the 'other half' of the houses within the framework.

The Elemental's half-house approach was first applied at Quinta Monroy making this project one of the most iconic in the Chilean incremental housing history. In the following years, Elemental housing and settlement designs have been adapted to at least twelve housing projects, including 2,045 houses, in Chile and Mexico. Elemental's approach has influenced the social and participative housing discussion 
in Chile and Latin America (Negro, 2016; Vergara-Perucich \& Boano, 2016). Quinta Monroy's housing typologies were adapted to the Monterrey project in Mexico built in 2010 and influenced the housing reconstruction projects proposed in the reconstruction plan for the City of Constitución following the devastating 2010 tsunami in Chile (MINVU et al., 2010).

Studies on incremental housing in Chile focus on diverse projects developed under government programs. However, the outcomes of Elemental's housing projects are rarely studied through a critical framework. The few studies of Quinta Monroy claimed the project's success as the residents moved in and started building extensions. This study observes the long-term process of resident-driven process of incremental housing extension and adaptation analyzing the limits of Turner's ethos 'freedom to build' within the Elemental's half-house framework. The findings from this research will provide insights of the impacts of incremental housing development that might influence the future policy directions of incremental housing programs in Chile and Latin America.

\section{Methodology}

This paper analyzes the process of incremental housing development in the iconic housing project of Quinta Monroy to investigate the types of resident-managed extensions built exceeding the designers' expectations. The complexities in the understanding of the process of housing extensions in Quinta Monroy requires a mixed research methodology. The analysis of the information focuses on an integrated understanding both the behavioral dimensions (qualitative) and empirical validations (quantitative) (Sreejesh \& Mohapatra, 2013). The data from Quinta Monroy was collected via questionnaires and interviews conducted in July-August 2017.

\section{Sample and participant's selection}

This paper observes the housing evolution more than 12 years after the residents received their houses in 2005. The initial contact with the community was with the former community leader that oversaw the upgrading process between 2003 to 2005 and the participants in this study were randomly selected. Residents' availability to participate in this research during the day, including weekends, was diminished due to their need to participate in the workforce. Residents initially preferred to fill the questionnaires by themselves and the questionnaires were collected by the researchers at convenient time. From the 18 participants in the questionnaire survey, ten agreed to be interviewed.

The details of the tools used for data collection are detailed below:

1. A closed question quantitative questionnaire seeking (a) general household data, (b) previous housing conditions, (c) initial conditions at Quinta Monroy, and (d) current housing conditions.

2. Qualitative, semi-structured interviews, extending data gathered by questionnaire to include (a) timelines for incremental additions, (b) difficulties encountered when undertaking incremental improvements, (c) future plans for improvements and (d) changes to the broader neighborhood.

3. Mapping of settlement conditions using research tactics including architectural drawings, photographic surveying and physical trace analysis.

4. Secondary data from government reports, books, and academic papers.

\section{Limitations of the study}

The authors have identified evidence, backed up by Millones (2017), that the Quinta Monroy settlement appears to lack the social cohesion that binds many other settlements together. The factors driving this are likely to be complex, extending beyond the scope of this study and the expertise of the authors. However, the challenge to include a significant number of residents' participating in this study, 
particularly in interviews and questionnaires, is likely to be a consequence of this fragmented social cohesion. To counter this limitation the analysis of the housing extensions was supported through direct observation and mapping based on fieldwork and aerial pictures taken. Hence, this study does not attempt to generalize the situation of all the residents, despite providing some evidence of the resident's aspirations and negotiations for housing extensions.

\section{Incremental housing and informality}

Critics of the self-help movement question people's agency to improve their living environments. Davis (2006) refers to 'illusions of self-help' while Seabrook (1996) stressed the infeasible transition from government-supported programs to entirely self-help programs. Similarly, authorities commonly express their concerns about allowing self-help adaptations or transformations of the government-built housing. Officials often observe that flexibility towards self-help construction would allow people building slums (Tipple \& Ameen, 1999), legitimize the existence of squatters and degraded neighborhoods in urban areas (Porio et al., 2004) or recreate the squatter conditions in which they used to live before (Carrasco et al., 2016).

Conversely, participative approaches for slum upgrading value the residents' inputs in the projects and their active involvement. However, they are understood as assisted projects, with permanent support from an external agency either government or non-government organizations. Contrarily, the incremental principles in the design of the incomplete houses which require the residents to build the missing part of the houses by themselves. Therefore, the limits between completion and distorting the initial idea might not be clearly stated as residents simply practice their given 'freedom to build'. Contrarily, Aravena's statement that 'with the right design slums and favelas may not be the problem, but actually a possible solution' (Aravena, 2014) might also encourage the sustainable and progressive development in projects like Quinta Monroy.

The context in which the project of the Quinta Monroy was developed coincided with changes in the housing approaches that challenged the conventional programs in the country. In early 2000s studies led the discussion around appropriateness of social housing and critiques for low living standards in the government-supported housing for the poor aiming to avoid the negative impacts of previous programs centered in achieving quantitative goals (Ducci, 1997; Muñoz, 2007; Rodríguez \& Sugranyes, 2005). Incremental housing initiatives in Chile have their origin in the 1950s although were interrupted during Pinochet dictatorship and were retaken as the country made its transition to democracy in 1990s (Arellano, 1977; Mora et al., 2020; Muñoz, 2007).

The Dynamic Social Housing Without Debt program implemented in 2002, aimed to target the poor and most vulnerable which at the moment were unable to access to property loans. The objective of the program was to combine flexibility and quality in the houses and settlements (Arriagada et al., 2004). The program encouraged innovation in the housing projects and the residents' active involvement in the co-production of their homes through subsequent extensions (Arriagada et al., 2004). Quinta Monroy was also developed under a parallel program called 'Chile Barrio' (Neighborhood Chile) which encouraged the involvement of multiple stakeholders to solve the problems of the poor, address social exclusion and promote housing and neighborhood improvements (Arriagada et al., 2004).

\section{Half 'good houses' of Quinta Monroy}

The Elemental project in Quinta Monroy was developed in the northern city of Iquique. The objective was to upgrade one of the last informal settlements located in the heart of the city. The settlement emerged in the 1960s mainly by migrants that occupied the land. The population gradually increased from 50 original families to 100 families in 2003. The site area of 5,722 sqm at some point 
allowed the residents to have small crops. Later the available space was reduced as the number of residents increased. Soon the settlement became a crowded labyrinthic cluster of self-constructed shelters built with timber and makeshift materials. The living conditions were precarious, $60 \%$ of the rooms lacked natural light and ventilation (Iacobelli \& Aravena, 2008). Residents lack basic services like electricity, water or sanitation, although there were few connections made informally. The settlement was also vulnerable to fires, like the one in 1980 that left 20 families homeless (Araya, 2005), and unsafe where crime and drugs permanently threaten the residents that forced them to organize in self-defense groups (La Estrella de Iquique, 2003).

In the early 2000s, the death of the manager of the settlement resulted in uncertainty about the ownership of the land and threats of eviction. Residents organized and requested the government for a permanent housing solution which allows them to remain in their original location. The government contacted Elemental through the Catholic University of Chile, for the design of the urban-architectural project of the Quinta Monroy (shown in Figure 1). Quinta Monroy was built under the Dynamic Social Housing Without Debt program and the residents received the ownership of their housing units following a residential condominiums joint property ownership format. The multiple challenges for Elemental included developing a housing project for 100 families, the limited land available and its extremely high cost that did not fit into the conventional budgets for social housing granted through government subsidies.

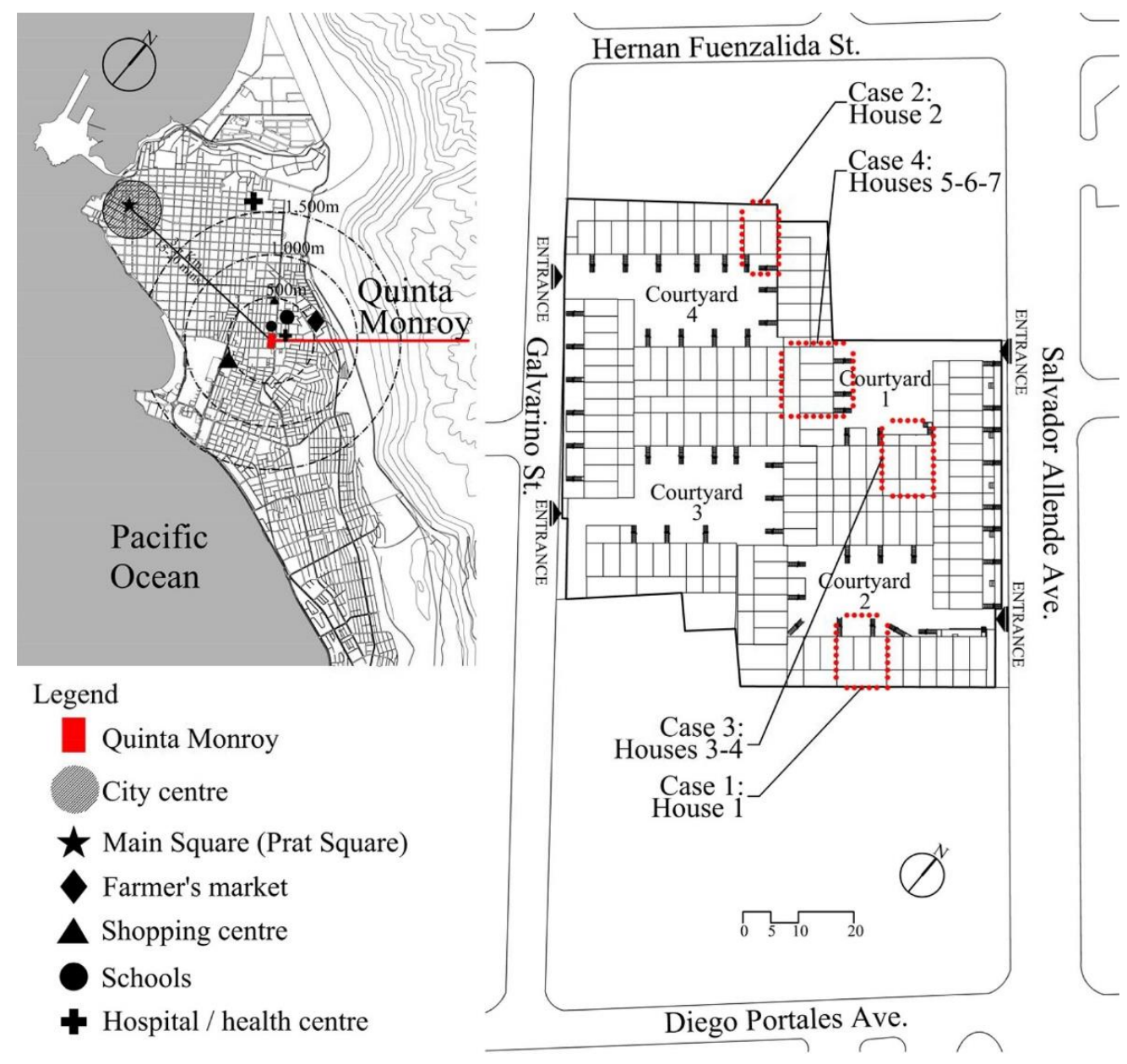

Figure 1 - Location and settlement layout of Quinta Monroy. Source: Authors (2020).

Quinta Monroy is a complex of 93 housing units organized in four courtyards aiming to promote community interaction and keep previous neighbors' affinities (Figures 1 and 2). The housing units are modular, each module is $3 \times 6 \mathrm{~m}$. There are two housing typologies. On the ground floor, 34 housing units of typology 1, each of them occupies three modules ( $54 \mathrm{sqm}$ ), two built and one to be completed. The 
lower units have a backyard of 27sqm that according to Elemental's expectations could be occupied up to $60 \%$ to achieve a total are for an extended house of 70sqm (Figure 2). Typology 2 (59 units) are duplex units built on top of units of typology 1. In the land occupied by one unit of typology 1, 1.5 units were built upstairs. Each duplex unit has two modules built ( $36 \mathrm{sqm}$ ) and two more modules to be extended to obtain a complete house of $72 \mathrm{sqm}$ (see Figure 2). Thus, Elemental claimed that they optimized the land building 2.5 houses in 54 sqm.

Elemental acknowledged a participatory process which involved the residents before and during the construction of the project, crucial for the temporary relocation of the residents which unfortunately some residents understood as a government measure to evict them permanently. The rest of the process was based on permanent consultations with the residents and workshops to take important decisions about the settlement layout, budget constraints, housing selection, site visits and construction of future housing extensions and settlement maintenance (Aravena \& Iacobelli, 2016).

Elemental admitted four main challenges for the Quinta Monroy project: (1) Establishment of the families in a consolidated urban area, (2) incremental construction without neighborhood deterioration, (3) safety and economic expansions, and (4) design with community participation. From the four challenges, two of them were achieved at the completion of the construction of the houses. Residents obtained the formal ownership of their houses built in-situ without suffering displacement. The families' opinions and demands were considered during the planning and throughout the construction process through participative approaches mentioned by Aravena \& Iacobelli (2016) and recognized by the families during the site visit in 2017 . However, the unpredictable nature of at least $50 \%$ of the future resident-driven construction does not prevent the eventual distortion and deterioration of the housing blocks and the settlement. Furthermore, it is uncertain that the works involved in the expansion of the houses would not burden the residents' precarious economies and produce constructions that would not compromise the residents' and community safety.

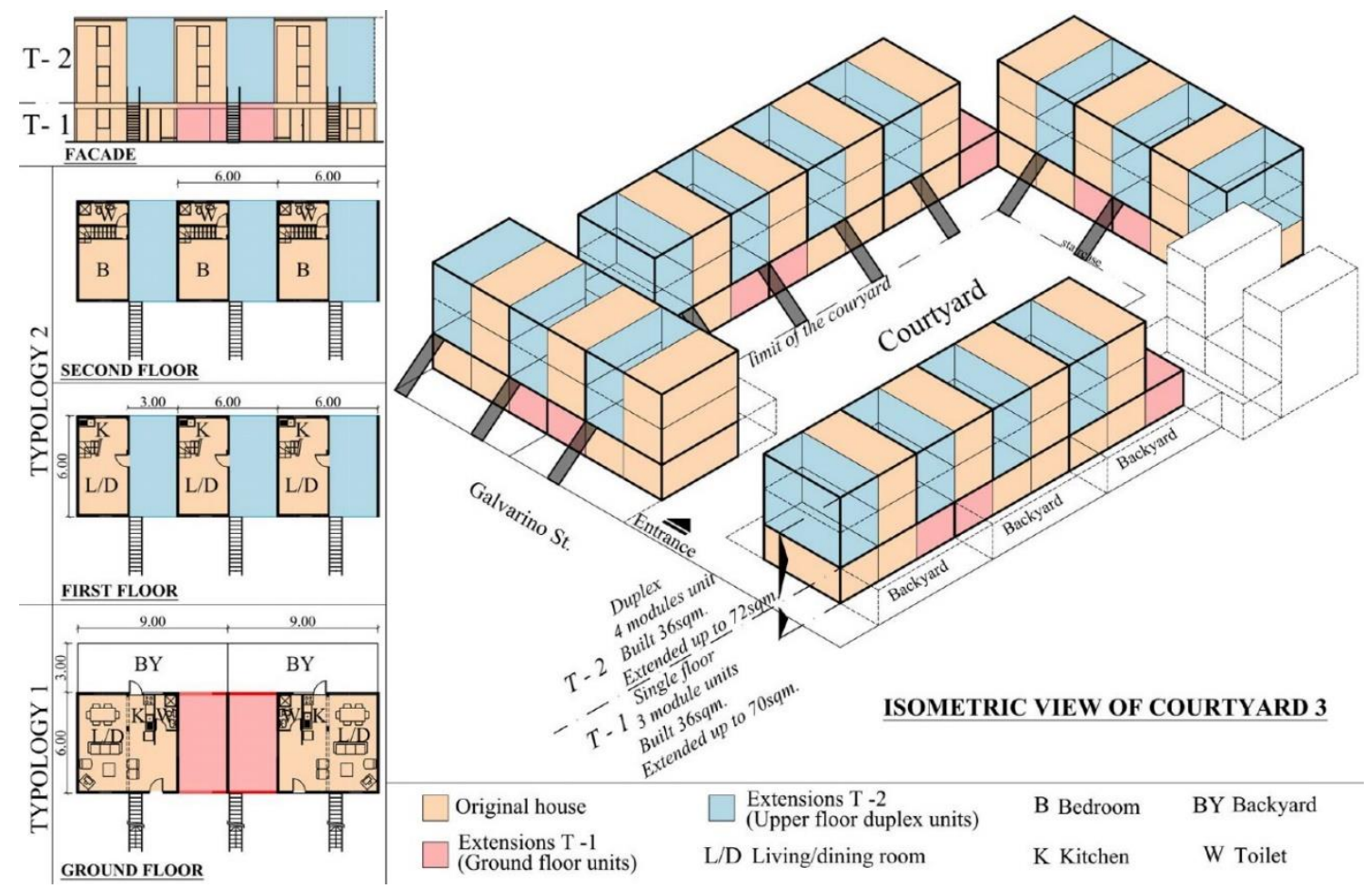

Figure 2 - Initial 'parallel housing' buildings and house typologies of Quinta Monroy. Source: Authors (2020). 


\section{Beyond the freedom to build}

Quinta Monroy represents a turning point in the development of social housing within the legal framework of housing supply through subsidies in Chile. Its impacts are unprecedented as the project was designed to alternate a formally built permeable structure that enables the unknown outcomes of the self-built extensions of the houses. Providing a safe structure as a frame aims to avoid the depreciation of the houses and the risks of collapse in case of earthquakes. Elemental provided shared and socially agreed-upon rules for the construction of the housing extensions (Aravena, 2010). Aravena (2010) claimed that the unknown additions to the initial houses might not result in the deterioration of the quality or the value of the property. Although, there might be possible aesthetics implications as they are randomly developed.

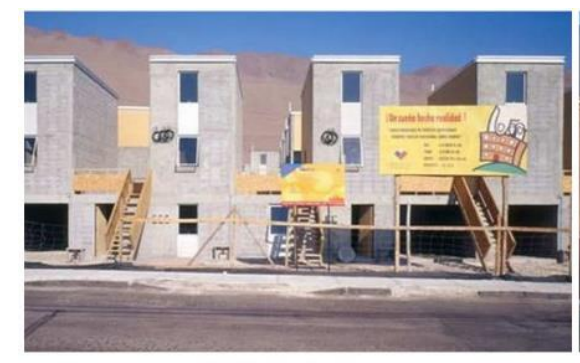

Houses in 2005 just after completion (Elemental, 2005)

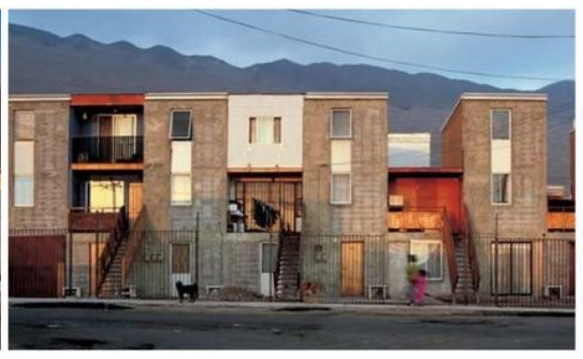

Housing extensions in 2009 (Palma, C., 2009)

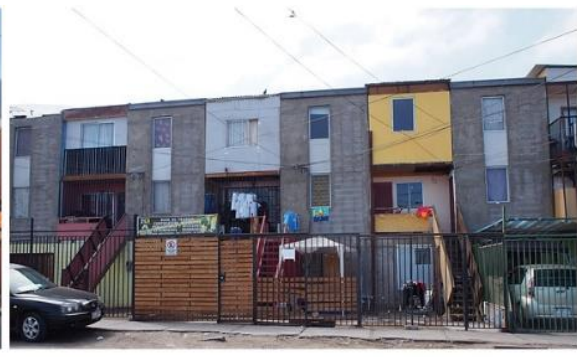

Housing extensions in 2017 (Authors)

Figure 3 - Evolution of incremental housing in Quinta Monroy. Source: Authors (2020) adapted from Elemental (2005) and Palma (2009).

Elemental (Iacobelli \& Aravena, 2008) envisaged some limitations for the self-built extensions through guidelines provided and defining the area of the initial and extended houses (Figure 2), and the use of lightweight materials for the self-built extensions. Designers predicted 'self-construction as customization, not deterioration' (Iacobelli \& Aravena, 2008) through the construction of the houses on the front edge of the lot, claiming that this would guarantee the quality of the urban front once the extensions are built. Additionally, building the half of the house that the families would never be able to achieve might guarantee the safety of the whole house of the intercalated open spaces to be filled by the residents. However, the reality of housing extensions might not necessarily follow the designers' plans, especially in the long-term. Figure 3 shows the evolution of the houses in Quinta Monroy, from the completion of the construction in 2005 (left), four years after the families moved in the house (center), and twelve years after the beginning of inhabitancy (right).

In twelve years, there have been substantial changes in the way how residents covered their housing needs which evidence progressive and ongoing housing extensions. The types of extensions built by the residents have been divided in planned and unplanned referring to whether Elemental considered them, or the residents built beyond the designer's plans for the expandable houses. An example of how Elemental's design has dramatically changed is presented in Figure 4 which presents the changes in the built and open spaces showing the impacts of the unplanned extensions. Houses backyards were occupied in 30 of the 34 typology 1 houses, eight occupied part of the courtyards intended to serve as a common interaction space for the community, and four households facing streets also occupied the frontal space. 


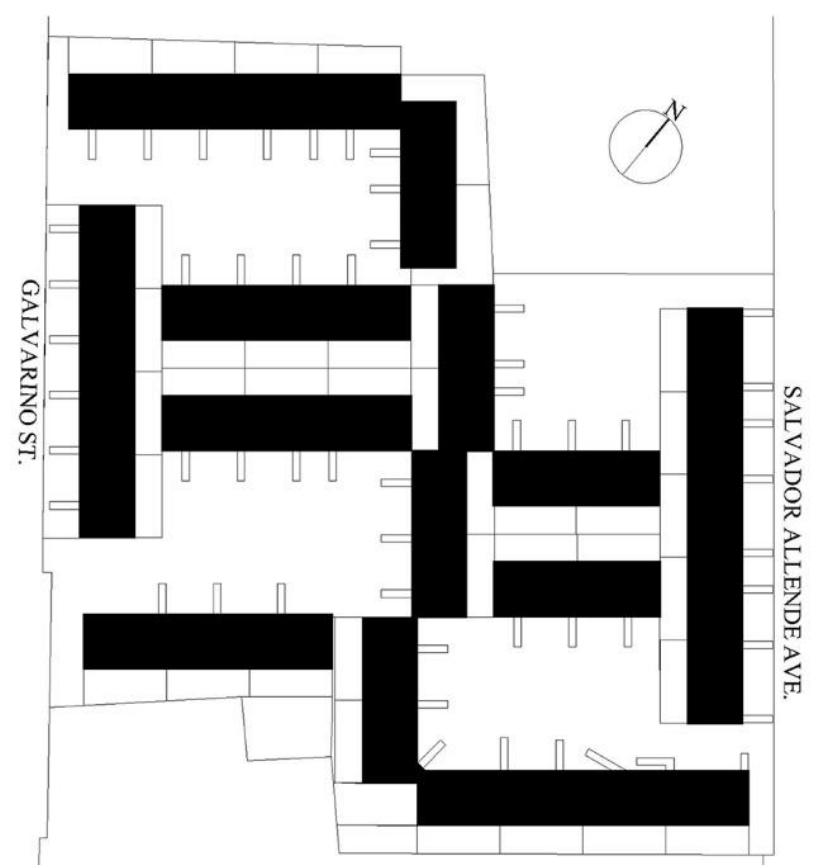

Just after completion in 2005

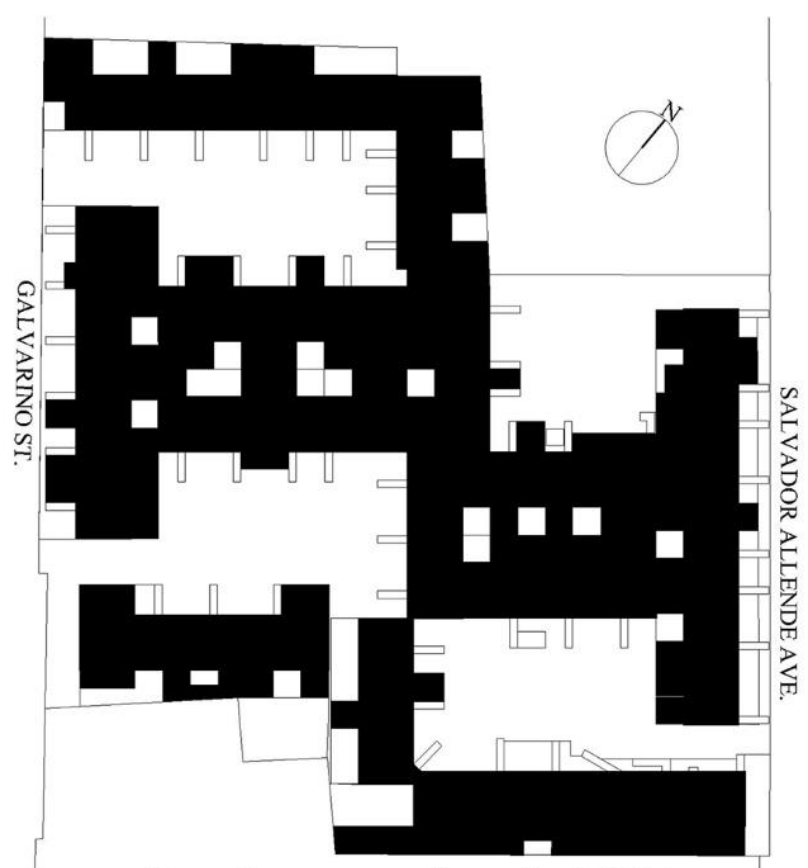

Housing extensions in 2017

Figure 4 - Changes in built and open spaces in Quinta Monroy. Source: Authors (2020)

A detailed observation of the extensions revealed that residents mostly followed the designers' recommendations for the materials of the extensions only using lightweight materials considering the structural characteristics of the houses. Although the housing extensions could be easily removed or replaced, from the residents' perspective these additions are permanent. Additionally, there are other types of additions which are temporary as they are not intended to be used in the long term. Such temporary extensions are gazebos or tents in front of the houses, and tarpaulin-covered backyards. In table 1 it is summarized the number of households that built certain kind of extensions. In principle, from the 93 households, only one has not modified its house. The other 92 houses show a different degree of extension and modification.

Figure 5 below shows that all the 34 houses of typology 1 were extended. From them, only one household built within the frame provided in the original house. The rest of households combined planned and unplanned with permanent and temporary extensions (see Table 1). This evidences that residents chose to use more space than the 70sqm planned for an extended house. Elemental expressed their concern about the habitability conditions, which are linked to appropriate natural lighting and ventilation in the houses depending on the windows facing the front and the backyard of each house on the ground floor. The site plans released by Elemental (Elemental, n.d.) suggest extensions in the backyard with an area of $16 \mathrm{sqm}$ which represents up to $60 \%$ of the $27 \mathrm{sqm}$ of the backyard in order to achieve the total of 70sqm for Typology 1 houses. However, the site visit revealed that only 13 households (38\%) occupied $60 \%$ of the backyard or less, while 21 households $(62 \%)$ occupied more than the $60 \%$ of the backyards. This shows that habitability conditions might be compromised for more than half of the residents of typology 1 units. 

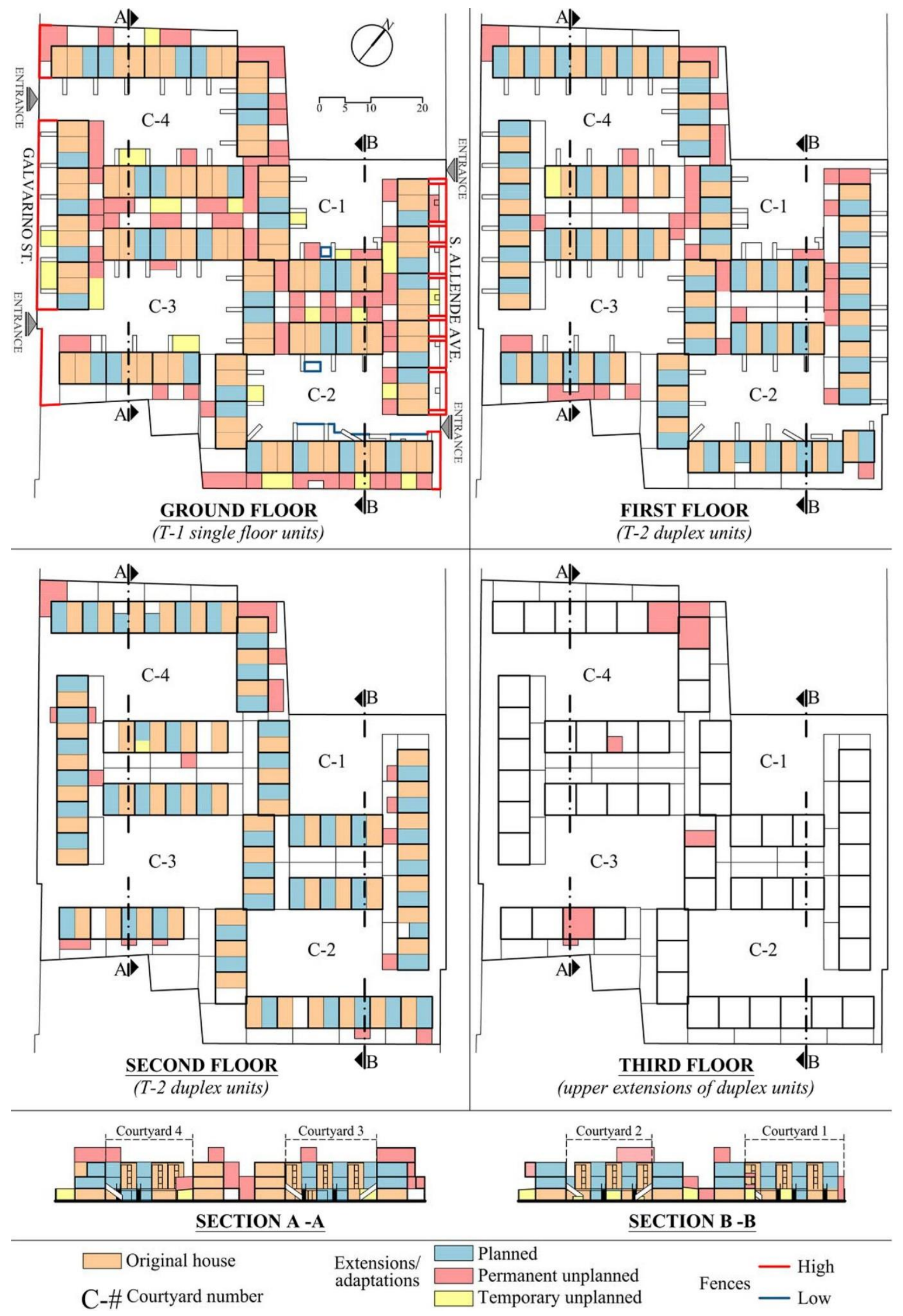

Figure 5 - Types of housing extensions per story and typology. Source: Authors (2020). 
Extensions in duplex housing units of typology 2 are presented in Figure 5. Only one of the 59 houses remain unmodified, and 32 (34\%) of them built the housing extensions within the planned frame. This shows that residents have achieved their needed or desired house as planned by Elemental at least for now. The rest of the households decided to build beyond the established limits set by designers (Table 1) and five of them expanded vertically building a third floor (Figure 5). The risk which involves the construction of extensions in front or the back of the planned houses is the limitation of natural lighting and ventilation is evident as the residents build extensions blocking the windows. From the 59 duplex houses, 13 households blocked 25\% of windows and four blocked from 37 to $50 \%$ of the windows.

The construction of unplanned extensions in the houses of typology 2 required the coordination with the neighbors of the lower units (typology 1). A total of 21 households coordinated their unplanned extensions, while five households decided to avoid potential problems with their downstairs neighbors and decided to build extensions either vertically or extending in the second floor only (Figure 5). One resident commented "I can't even paint the façade of the house because I would have to coordinate with my neighbors upstairs, and I don't think we might agree" (Female, 50; Interview 9, Aug. 5, 2017)

Table 1 - Types of housing extensions

\begin{tabular}{llllll}
\hline \multirow{2}{*}{ Housing Typology } & \multirow{2}{*}{ Unmodified } & \multicolumn{4}{l}{ Extended/adapted } \\
\cline { 3 - 6 } & & $\mathrm{P}$ & $\mathrm{P}+\mathrm{PU}$ & $\mathrm{P}+\mathrm{TU}$ & $\mathrm{P}+\mathrm{PU}+\mathrm{TU}$ \\
\hline $\mathrm{T}-1(34)$ & $0 \%(0)$ & $1.07 \%(1)$ & $20.43 \%(19)$ & $1.07 \%(1)$ & $14.13 \%(13)$ \\
$\mathrm{T}-2(59)$ & $1.07 \%(1)$ & $34.41 \%(32)$ & $26.87 \%(24)$ & $2.17 \%(2)$ & $0 \%(0)$ \\
\hline
\end{tabular}

Notes: 92 of the 93 households extended their homes. P=Planned extensions. PU=Permanent unplanned extensions/ adaptations. TU=Temporary unplanned extensions/adaptations. Source: Authors (2020).

Fences are another way of appropriation of the space which is not roofed. Households facing streets decided to build high fences, mostly driven by safety reasons "the houses along the main avenues are more vulnerable, that is why they built fences" (Male, 49; Interview 10, Aug. 5, 2017). Residents facing S. Allende Ave. built fences of accessing each house and they were covered by plywood to block the view from the exterior (Figure 6). Houses facing Galvarino St. also have high fences, although they are shared between houses in the ground floor and upper housing units and views from outside are not blocked in most of the cases. Additionally, three houses in courtyard 2 built low fences to define the space they use as an extension of their homes or to define green spaces. Once residents constructed fences to define their extended space, it results easier for them to start making temporary extensions that would become permanent within these limits already established, one resident mentioned: "I would like to build the wall in front with concrete blocks and I want to make the concrete flooring" (Female, 84; Interview 7, Aug. 1, 2017). 


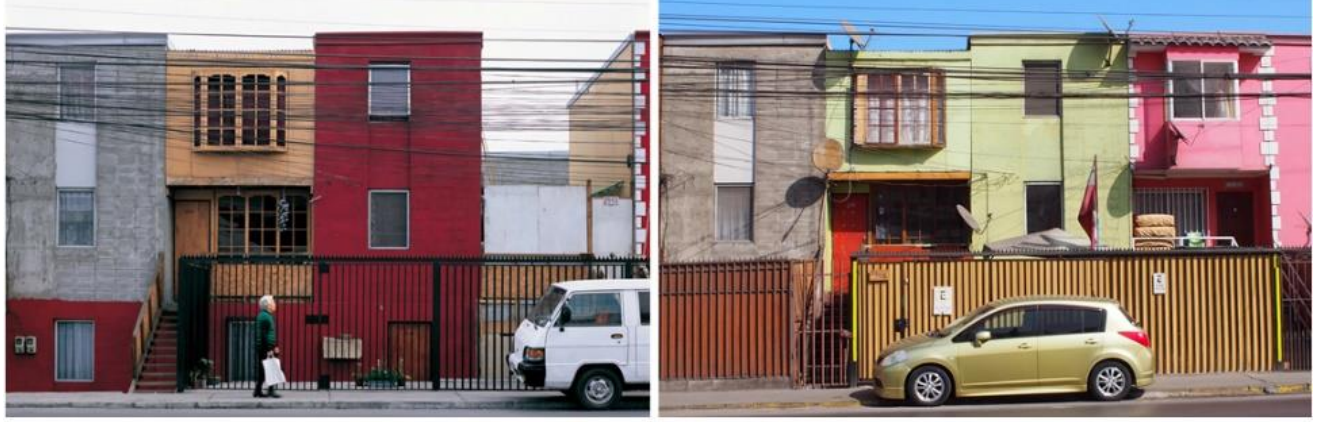

Houses facing Salvador Allende Avenue

In 2009 in the left (Palma, C. 2009) and in 2017 in the right (Authors)
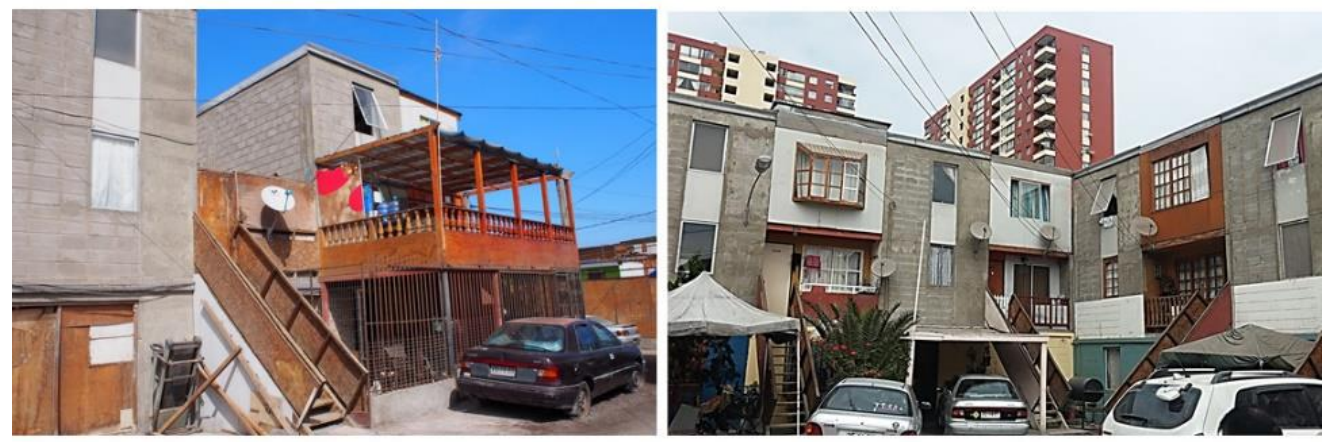

Permanent (left) and temporary (right) frontal extensions in courtyards.

Figure 6 - Changes in the construction of extensions and frontal extensions in courtyards. Source: Authors (2020) and adapted from Palma (2009).

\section{Behind the housing extensions}

Residents have expressed multiple reasons for their self-managed housing extensions. The different changes in the residents' family, financial and living conditions over time create complex decisionmaking processes that resulted in their efforts to improve their housing. However, two main interconnected reasons were mentioned during interviews. Firstly, the need for additional living spaces to accommodate the family members, "I have extended the house mainly to accommodate my children and grandchildren, although the house is becoming smaller now" (Female, 70; Interview 1, Jul. 29, 2017). Also, the need to provide privacy to the members of the family, "we decided to build the bedrooms in the back of the house because we needed more privacy for my son and my daughter, also because later our grandson was born" (Female, 49; Interview 2, Jul. 30, 2017). Secondary reasons were associated with security and the needed for storage spaces.

Extensions initially built to accommodate family later became spaces for sub-letting, "at first I wanted a more private space for my daughter. Later she moved out and I built an independent access staircase, now it is an apartment that I rent out" (Female, 60; Interview 4, Aug. 6, 2017).

These views of how the housing extensions started echoed the findings identified in Alan Gilbert's study in Colombia (Gilbert, 2017) where housing transcended from residential use to become a source of income as residents rent out spaces or establish businesses. However, factors related to the centrally convenient location of Quinta Monroy might also contribute to the densification of the houses as it expands to accommodate additional households. A homeowner explains why she left but keeps the ownership "I moved to a nearby place because I don't like the community here... but I keep my house in Quinta Monroy because of the convenient location near to the main vegetable market in the city and near to the city center" (Female, 50; Interview 9, Aug. 5, 2017). This shows how the strategic location of Quinta Monroy presents another characteristic of the houses in Quinta Monroy. The strategic location attracts tenants that reside in the extra rooms or subdivided units. 


\section{Beyond incremental housing}

Each household in Quinta Monroy was given the freedom to spontaneously perform extensions adding at least $50 \%$ of the initial house according to Elemental design. The evidence from twelve years of progressive housing modification shows that most of the residents (59 out of 93) crossed the limits anticipated by the designers. At the housing level, there are specific types of extensions that show the diversity and levels of control that residents have over their houses and the different drivers and motivations. These 'uncontrolled' self-construction might not necessarily be the result of what people want but what people can achieve (Aravena, 2010). Additionally, studies in long-term housing adaptation in Chile observed particular trends. Sepúlveda et al. (1994) and Vergara et al. (2019) found that residents gradually have withdrawn from community initiatives and focused on the improvement of the family home. However, Sepúlveda et al. (1994) also reported that residents' interaction with their community may remain at reduced scale, mainly among contiguous neighbors.

The Quinta Monroy's design encourages residents' negotiation for the construction of extensions, especially beyond the framework set by Elemental. Therefore, an individual or group inside the settlement present its complexity beyond apparent patterns and evidence participation of single or multiple households as actors who control the process of housing modification. In this research, seven participant households were considered for analysis divided into four cases in which are presented the individual and group capacities to coordinate and build housing extensions.

\section{Case 1}

This case presents an individual household process of housing adaptation and extensions of House 1 (Figure 7) is a house typology 1 in the ground floor located in the courtyard 2 (Figure 1). The house owner is a senior lady who moved in with her son occupying two-thirds of the house as a 'main house' and adapted the remaining one third 'sub-house' to rent and get an extra income. Later her daughter moved in the sub-house with her family. This is one of the few interior houses (facing the courtyards) that built a low fence to demarcate what they consider their property and it is currently used as a terrace.

The homeowner adapted the main-house extending the livable-area occupying the backyard just leaving an area of $2.25 \mathrm{sqm}(1.5 \times 1.5 \mathrm{~m})$ for ventilation and lighting of rooms in the rear of the house. Two bedrooms get natural lighting through small windows facing the kitchen next to the reduced backyard. The kitchen and a laundry room have also been reduced, and the improved bathroom remains in its original location. The social spaces of the house, living and dining room, remain in front and have not been substantially altered. The sub-house now occupies all the area of the original backyard and is home to a family of four and includes three bedrooms, a bathroom, a kitchen space and a living room. All the rooms are small, lack windows and can barely accommodate a bed. 
House 1

(Typology 1 - single floor)
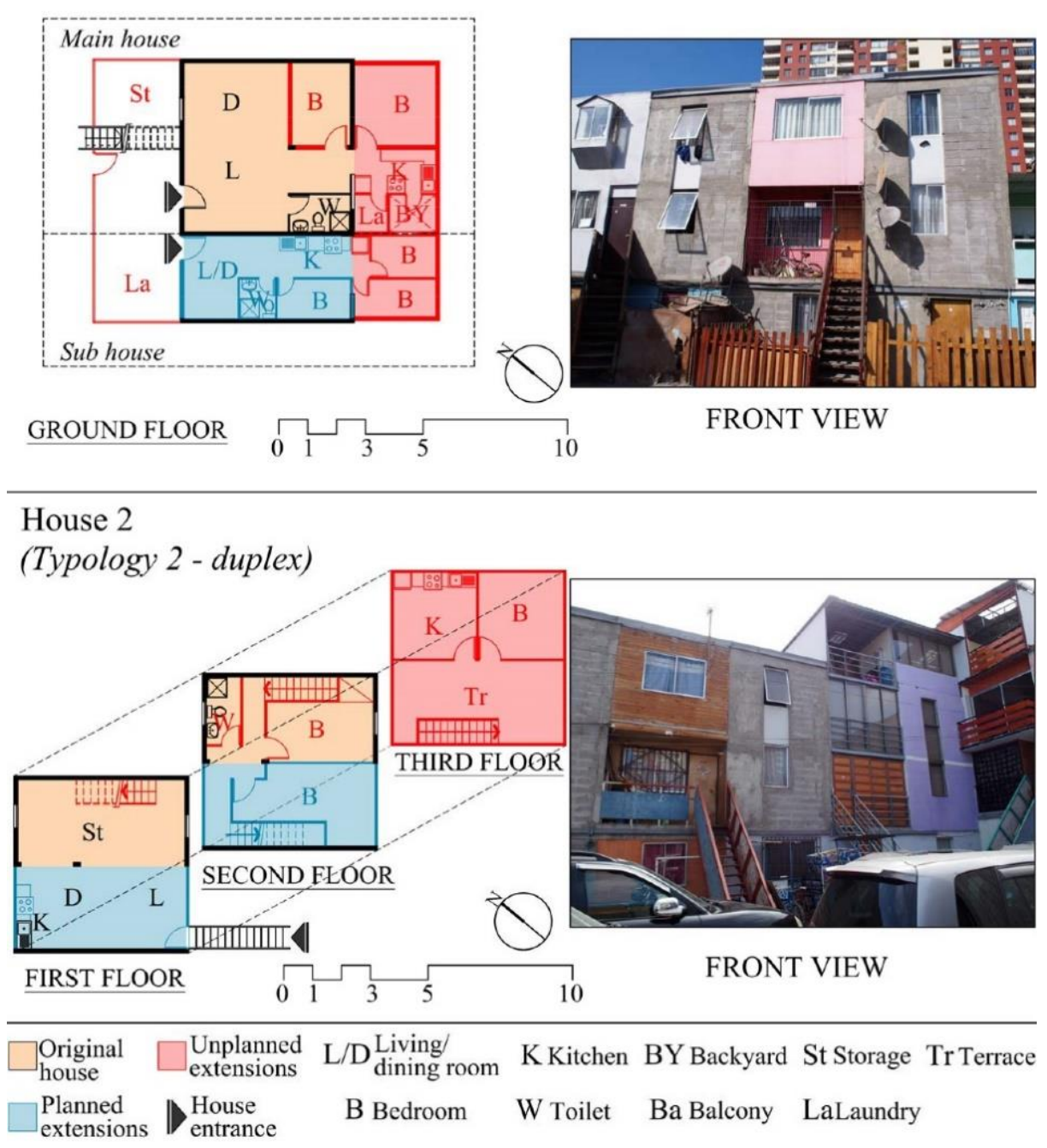

Figure 7 - Isolated housing extensions. Source: Authors (2020).

\section{Case 2}

House 2 shown in Figure 7 is a duplex house located on the first and second floors in courtyard 4 (Figure 1). The homeowner was granted the house and lived alone for the first two years. Once his partner and her son moved into the house, he was motivated to expand the house first completing the other half of the house and later the residents expanded on the roof. In February 19th, 2012 there was a fire started by a welding machine while building extensions and required the family to rebuild their home. Currently, the first floor of the house has a living and dining room and storage space essential for the family business. There are two bedrooms on the second floor, one used for the parents and one to rent to the workers that collaborate in the family business. The third floor is intended to be the apartment for the son and includes a bedroom, kitchen and terrace that later will be improved as a living room. The family declined to build horizontal extensions to avoid coordination with neighbors.

\section{Case 3}

Presented in Figure 8, this is a group of two households from House 3 (typology 1 in the ground floor) and House 4 (duplex in the first and second floors) that are in courtyard 1 (Figure 1). The household of the House 3 is composed of seven people, the mother of the family, two sons, two grandsons 
and two granddaughters. The extended family decided to build two bedrooms in one-third of the house, which extended to the back occupying only one-third of the backyard. The family kept the original layout of the living and dining room, as well as the kitchen and bathroom. The family uses the frontal space as storage and terrace. This space is covered by the balcony of the upper floor.

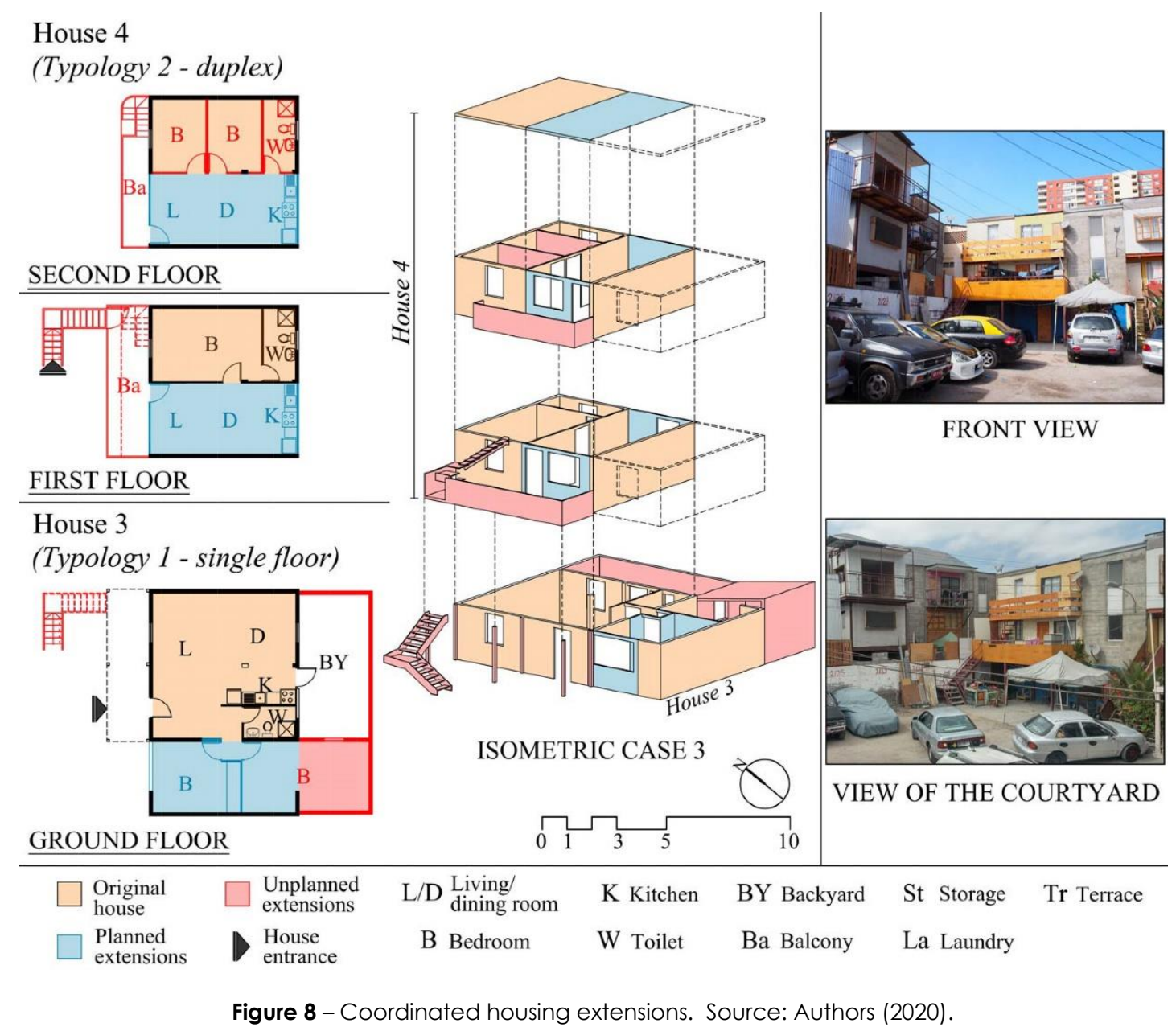

The homeowner of House 4 (Figure 8) are a nuclear family of both parents and their daughter. They initially built the other half of the house adding a living room on the first floor and bedrooms on the second floor. After the death of the father of the family, the daughter moved upstairs dividing the house into two apartments. The family changed the stairs to access the house, adding a balcony which occupies an area in front of the house, and which was built in coordination with the residents of House 3. Once the house was divided the internal stairs were removed and there is independent access through stairs in front, creating a second balcony on the second floor to access the upper unit. The homeowner changed the layout of the second floor to be suitable for renting to a tenant that is currently living in the unit after the daughter moved out in 2015.

\section{Case 4}

Presented in Figure 9, this case a group of three housing units, House 5 typology 1 in the ground floor and Houses 6 and 7 which are typology 2 and located in courtyard 1 (Figure 1). The single parent family is led by a mature lady who lived with her three sons and three daughters and the grandmother moved in four years ago. The family extended the house to accommodate the family, giving more privacy to the grandmother whose bedroom is on the ground floor and next to the house entrance. A corner of the living room was slightly modified to serve as a sleeping space, while a 
bedroom was built in the backyard. The house owner effectively coordinated with the owner of House 7 to build two bedrooms on an upper floor due to the need for additional livable spaces. Later the family moved the kitchen and the bathroom to the backyard and build a staircase to access the upper bedrooms. Despite the lack of awareness of the decreasing living conditions resulting from covering all the backyard, the homeowner observed that this was the only option to accommodate the 8 members of the family. The homeowner expressed her initial disappointment because of the unfinished house she received, after extending she feels proud of her achievements. She also acknowledged the good quality of construction of the Quinta Monroy houses tested during the 2014 earthquake that hit Iquique.

House 6

(Typology 2 - duplex)

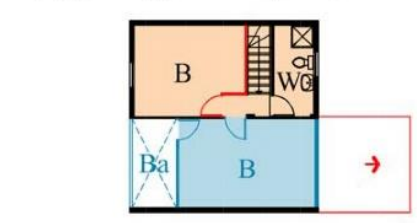

SECOND FLOOR

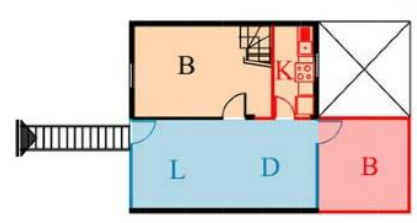

FIRST FLOOR

House 5

(Typology 1 - single floor)

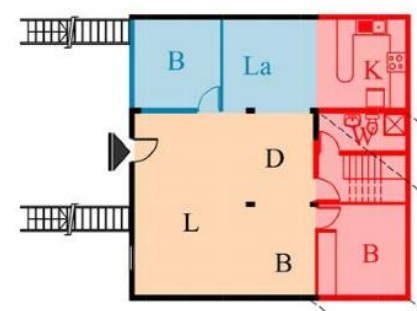

GROUND FLOOR
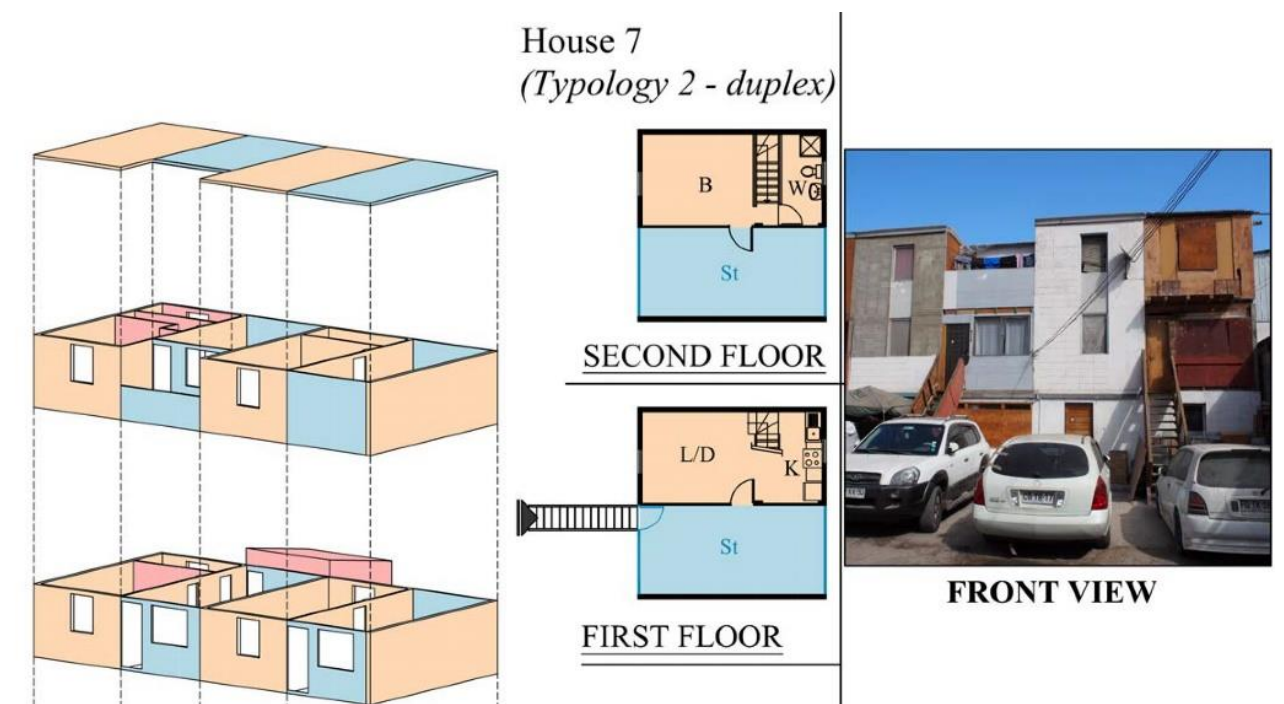

FRONT VIEW
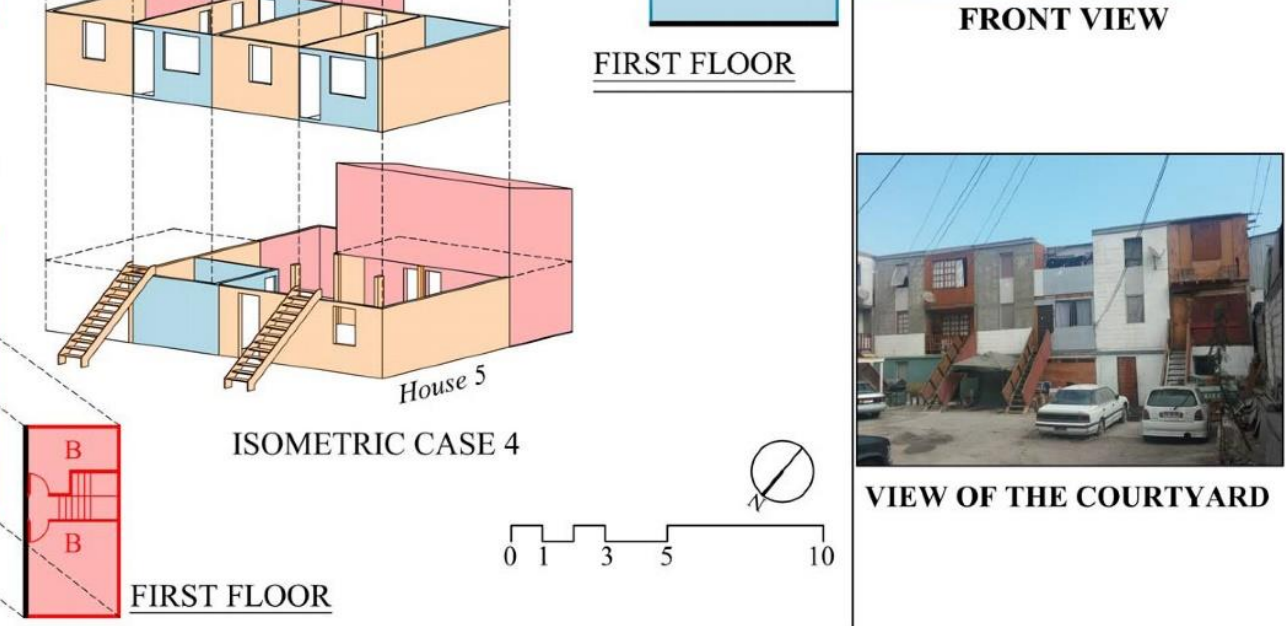

ISOMETRIC CASE 4

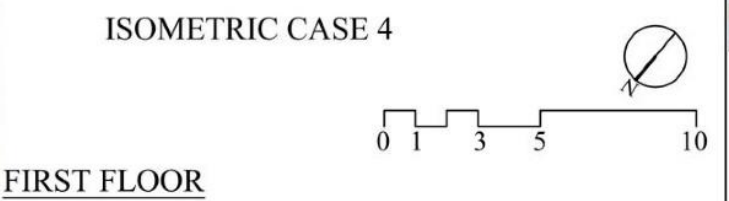

VIEW OF THE COURTYARD

FIRST FLOOR
K Kitchen BY Backyard

Ba Balcony
St Storage
La Laundry

$\operatorname{Tr}$ Terrace

Figure 9 - Multiple households coordinated extensions. Source: Authors (2020).

The household of the duplex unit in the right (House 7) is a single mature man who works in construction and one of the local builders hired by the neighbors to complete their houses. However, he performed few changes in his house and expressed a lack of motivation to further improve his living environment. He allowed the neighbor downstairs (House 5) to expand vertically in the backyard. He precariously extended to fill the other half of his house but only to have more storage spaces.

The owner of House 6 coordinated with the downstairs neighbor (House 5) to extend a bedroom in the back, so the kitchen of House 5 could be covered. Currently, there is an extended family of seven members renting House 6 with all modifications made before they moved in 2015. The family decided to move to Quinta Monroy due to its convenient location close to commercial areas and schools for the 
younger family members. This house has an extra bedroom in the back and a terrace on the upper level which is used as a laundry.

\section{Discussion}

The Quinta Monroy project been designed to find a balance between top-down planning approaches, and the bottom-up transformation of the houses by their inhabitants over time (de Chile \& Verona, 2006). The long-term progressive development of the settlement and houses reveals the residents' active involvement in the production of their own houses. Most of the households built additional spaces beyond those predicted by the designers at Elemental. Evidence shows the process of incremental housing construction has impacted upon the residents' interaction as a community. However, neighbors' communication remained at a reduced scale among contiguous neighbors which facilitated the construction of housing extensions that involve multiple households. Although these issues might not be exclusive of Elemental's housing projects.

The unregulated and unknown housing progression is evidenced by the larger area occupied and more complexities in the adaptation of the houses which are the result of changing residents' needs, aspirations, resources and capacities. Among the main priorities of Elemental architects were avoiding the degradation of the settlement and the safety in the construction of extensions. However, they also recognized the impossibility to control the houses' extensions. Table 2 below gives an insight of resident's capacities to expand their houses and the importance to focus on the extensions as these can double the original housing provided. Residents' agency has been evidenced although potential risks for the residents' wellbeing also emerged.

The information collected in the site shows that there are undesirable and unexpected outcomes that affect the quality of life of the residents. These are related to the loss of basic conditions of habitability in the houses. The first indicator presented was the lack of natural lighting and ventilation due to unplanned housing extensions in most of the houses which have a direct impact in the physical and mental health of the people (D'Alençon et al., 2010; WHO, 2010).

The second aspect observed in Quinta Monroy is the risk is the overcrowding or the reduced livable area for the residents. Floor area per person is a key indicator of housing quality (UN-Habitat, 2001, p. 30-31) which in case it is insufficient it may result in the deterioration of human settlements leading to slum conditions (UN-Habitat et al., 2002). The transition from nuclear to extended families led to multifamily house occupation, which in extreme cases, are limited to 5.5sqm per person as seen in house 3 (see Table 2). However, another phenomenon that could contribute to the limited living area is the subdivision of the units in sub-houses as seen in three houses analyzed in this study. In house 1 , areas as small as $7 \mathrm{sqm}$ per person are observed. This is clearly under the national housing standards and even under the reduced standards for social housing in Chile. The Chilean law establishes an occupancy load of $15 \mathrm{sqm}$ per person for houses up to 60sqm, and 20sqm per person for housing units between 60 to 140sqm (MINVU, 2002) and a minimum of 11sqm for social housing (D'Alençon et al., 2010). However, the Chilean regulation does not recognize overcrowding in terms of floor area per person but based on people sharing bedrooms (MINVU, 2004). 
Table 2 - Housing extensions and areas per person

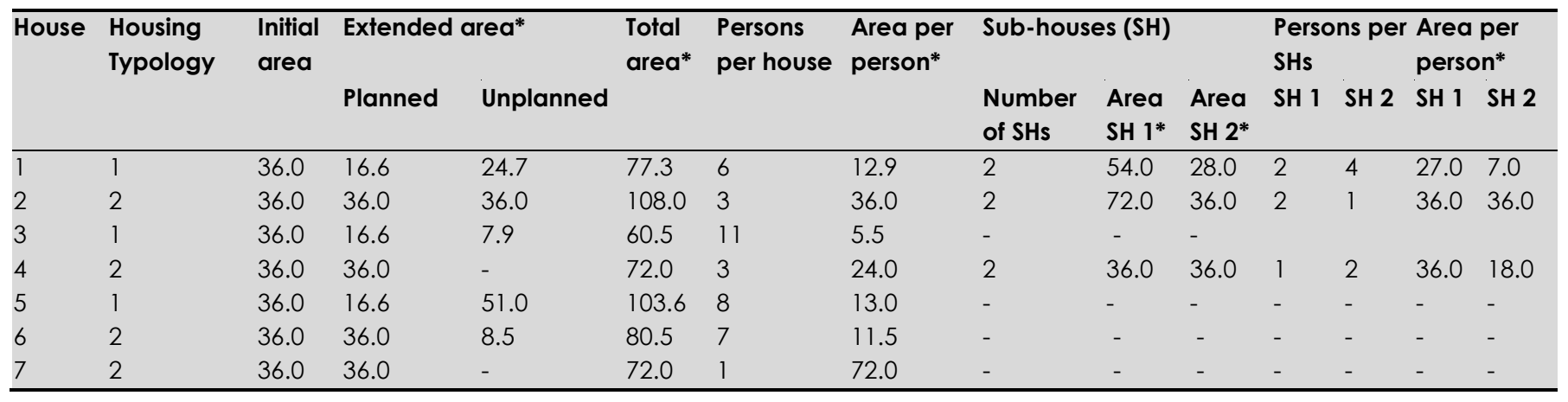

Note: *Area in square meters (sqm). Source: Authors (2020).

A third indicator is the safety of the housing extensions (Aravena \& Iacobelli, 2016). Residents expressed their concern related to the safety in the process of construction of the extensions. However, between 2012 and 2014 two fires have been reported in Quinta Monroy by the residents and even the local media (Vallejos, 2012). These incidents were caused accidentally during the construction of extensions by welding sparks that caused fires that affected neighboring homes. Thus, individual housing improvements may put on risk the collective environment. Although the level of awareness of the residents about other potential risks is low, such as earthquakes, it is remarkable that the houses' structure has been remained stable after the 2014 earthquake that hit Iquique.

\section{Conclusions}

The redevelopment of the Quinta Monroy settlement has proven to be a collaborative effort between the architects and the residents who have been entrusted to incrementally self-manage their housing to meet their own needs and aspirations. Despite the outcomes anticipated by the design team there is significant evidence that much of this process has been undertaken in an organic and diverse manner that has been informally negotiated between residents aiming to improve living conditions and provide livable spaces for family members. However, it seems that there are no boundaries for incrementality despite the designers' intent to provide a framework to contain the construction of extensions. Housing adaptations have exceeded the predicted plans and introduced shortcomings that challenge minimum habitability conditions as residents prioritize their space and financial needs.

This paper has shown that residents are replicating the same type of housing development evident in their former informal settlement. In many cases this has resulted in degradation of living conditions escalating to levels that would compromise their amenity and safety. Therefore, there is the risk of the re-creation of urban inequalities suffered by the most socio-economic vulnerable groups. However, this might not merely the result of a resident-driven process of degradation and 'slumization' of their globally acclaimed 'model settlement'. The outcomes observed are the result of the shortcomings of a mass-designed housing planned for unassisted individual development of each house which dismisses the implications in the neighborhood and community. Certainly, a 'good housing design' might not be enough to prevent the eventual degradation of the living conditions of its residents and their community.

The Quinta Monroy represents a valuable attempt to re-think the qualitative dimensions of the housing problem rather than focusing only on the quantitative housing deficits. However, it also evidences the lack of human-centered development of the settlement as a changing society, not only restricted to a physical environment. The participative processes that were always claimed by Elemental ended the day residents received their homes. Thus, the current state of the Quinta Monroy presents a physical progressive individual housing development that does not encompass a progressive collective development. Based on the lessons from Quinta Monroy, institutional support needs to be reconsidered 
observing residents' awareness of quality in their living conditions, safety, community leadership and cohesion as pillars for the development of the physical and social dimensions of the incremental housing and neighborhood.

\section{Acknowledgements}

The authors would like to thank the residents of Quinta Monroy for their generous participation in this research program, Julio Carrasco (B. Arch.) for his valuable support during the collection of information.

\section{References}

Aravena, A. (2010). Elemental-Interview. Perspecta, 42, 85-89. Retrieved on June 03, 2018 from www.jstor.org/stable/41679225

Aravena, A. (2014). ¿Mi filosofia arquitectonica? Incluir a la comunidad en el proceso [My architectural philosophy? Engaging the community in the process]. TED Global. Retrieved on June 03, 2018 from

https://www.ted.com/talks/alejandro_aravena_my_architectural_philosophy_bring_the_community_into_the_process? language5es

Aravena, A., \& Iacobelli, A. (2016). Elemental: manual de vivienda incremental y diseño participativo [Elemental: incremental housing and participatory design manual]. Ostfildern: Hatje Cantz.

Araya, M. (2005). La pionera de la Quinta Monroy [The pioneer of Quinta Monroy]. La Estrella de Iquique. Retrieved on September 8, 2017 from

https://www.estrellaiquique.cl/prontus4_nots/site/artic/20051113/pags/20051113090809.html

Arellano, J. P. (1977). Elementos para una política de vivienda social. Revista EURE-Revista de Estudios Urbano Regionales, 5(14). Retrieved on July 10, 2020 from http://eure.cl/index.php/eure/article/view/895/10

Arriagada, C., Sepúlveda Swatson, D., Cartier Rovirosa, E., \& Gutiérrez Vera, C. (2004). Chile: Un siglo de políticas en vivienda y barrio [Chile; A century of Housing and Neighbourhood Policies]. Retrieved on July 10, 2020 from: http://biblio.uchile.cl/client/es_ES/sisib/search/detailnonmodal/ent:\$002f\$002fSD_ILS\$002f0\$002fSD_ILS:525102/ ada?qu=Arriagada + Luco $\% 2 \mathrm{C}+$ Camilo.\&ic $=$ true

Carrasco, S., Ochiai, C., \& Okazaki, K. (2016). Impacts of resident-initiated housing modifications in resettlement sites in Cagayan de Oro, Philippines. International Journal of Disaster Risk Reduction, 17, 100-113.

D’Alençon, R., Justiniano, C., Márquez, F., \& Valderrama, C. (2010). Parámetros y estándares de habitabilidad: calidad en la vivienda, el entorno inmediato y el conjunto habitacional. En Camino al Bicentenario Propuestas para Chile.

Santiago, Chile: Gobierno de Chile, Pontificia Universidad Catolica de Chile, Camara de Diputados Chile \& Biblioteca del Congreso Nacional de Chile. Retrieved on September 8, 2017 from https://politicaspublicas.uc.cl/wpcontent/uploads/2015/02/parametros-y-estandares-de-habitabilidad.pdf

Davis, M. (2006). Planet of slums. New York: Verso.

de Chile, T., \& Verona, I. (2006). ELEMENTAL Program: Rethinking Low-Cost Housing in Chile. PRAXIS: Journal of Writing + Building, (8), 52-57. Retrieved on April 15, 2019 from www.jstor.org/stable/24328975

Ducci, M. E. (1997). Chile: el lado obscuro de una política de vivienda exitosa. EURE - Revista Latinoamericana de Estudios Urbano Regionales, 23(69). Retrieved on April 15, 2019 from

http://www.eure.cl/index.php/eure/article/view/1164

Elemental. (n.d.). Elemental, four Incremental Housing Projects. Retrieved on February 5, 2018 from http://www.elementalchile.cl/en/

Elemental (2005). Quinta Monroy / ELEMENTAL, ArchDaily. Retrieved on August 15, 2017 from https://www.archdaily.com/10775/quinta-monroy-elemental?ad_medium=gallery

Gilbert, A. (2017). ¿Una casa es para siempre? Movilidad residencial y propiedad de la vivienda en los asentamientos autoproducidos. Territorios, (6), 51-73. 
Goethert, R. (2010). Incremental housing. Monday developments, 9, 23-25.

Iacobelli, A., \& Aravena, A. (2008). Elemental: Housing As an Investment Not a Social Expense. In Ruby, I., \& Ruby, A. (Eds.), Urban transformation (p. 244 - 357). Berlin: Ruby Press.

La Estrella de Iquique. (2003, 1 October 2003). "Fumones" intentaron quemar la Quinta Monroy ["Addicts" tried set fire the Quinta Monroy]. La Estrella de Iquique,. Retrieved on November 22, 2017 from

https://www.estrellaiquique.cl/site/edic/20031001001255/pags/20031001002406.html

Millones S., Y. (2017). La otra mitad de la Quinta Monroy [The Other Half of the Quinta Monroy]. Revista de Arquitectura, 22(32), 67-72. https://doi.org/10.5354/0719-5427.2017.46147

MINVU. (2002). Ordenanza General de Urbanismo y Construcciones. D.S. 217 - D.O. 20.02.02. . Santiago, Chile: Ministerio de Vivienda y Urbanismo [Ministry of Housing and Urban Planning]. Retrieved on August 15, 2017 from https://www.bcn.cl/leychile/navegar?idNorma=194720

MINVU. (2004). El Déficit Habitacional en Chile: medición de los requerimientos de vivienda y su distribución espacial. Serie VII: Política Habitacional y Planificación. Santiago, Chile: Ministerio de Vivienda y Urbanismo [Ministry of Housing and Urban Planning]. Retrieved on August 15, 2017 from https://catalogo.minvu.cl/cgi-bin/koha/opacretrieve-file.pl?id=07512a141cbbcabff234ace8201cf26b

MINVU, Municipio de Constitución, \& Arauco. (2010). Plan de Reconstrucción Sustentable PRES Constitución [Plan for the Sustainable Reconstruction of Constitucion]. Santiago: Chile. Retrieved on February 02, 2013 from http://minvuhistorico.minvu.cl/incjs/download.aspx?glb_cod_nodo=20100910140027\&hdd_nom_archivo=Plan_Maes tro_PRES_ConstituciónB3n_Agosto_2010.pdf

Mora, R., Greene, M., Gaspar, R., \& Moran, P. (2020). Exploring the mutual adaptive process of home-making and incremental upgrades in the context of Chile's Progressive Housing Programme (1994-2016). Journal of Housing and the Built Environment, 35(1), 243-264. https://doi.org/10.1007/s10901-019-09677-9

Muñoz, C. (2007). Vivienda Progresiva, un programa del sector público que se potenció en el hábitat rural chileno. Revista INVI, 22(59). Retrieved on May 10, 2018 from http://revistainvi.uchile.cl/index.php/INVI/article/view/293/922

Negro, V. (2016). Arquitectura Participativa en America Latina [Participatory architecture in Latin America]. Casa del Tiempo, 3(32). Retrieved on July 02, 2019 from

http://www.uam.mx/difusion/casadeltiempo/32_sep_2016/casa_del_tiempo_eV_num_32_42_45.pdf

Palma, C. (2009). Quinta Monroy / ELEMENTAL, ArchDaily. Retrieved on August 15, 2017 from

https://www.archdaily.com/10775/quinta-monroy-elemental?ad_medium=gallery

Porio, E., Crisol, C. S., Magno, N. F., Cid, D., \& Paul, E. N. (2004). The Community Mortgage Programme: An innovative social housing programme in the Philippines and its outcomes. In Mitlin, D., \& Satterhwaite, D. (Eds.), Empowering squatter citizen: Local government, civil society, and urban poverty reduction (p. 54). London: Earthscan.

Rodríguez, A., \& Sugranyes, A. (2005). Los con techo. Un desafío para la política de vivienda social Santiago de Chile [Those with a roof: A challenge for social-housing policy]. Santiago,, Chile: Ediciones SUR.

Seabrook, J. (1996). In the cities of the south: Scenes from a developing world. London: Verso.

Sepúlveda, R., Muñoz, P., Puente, P. d. l., \& Torres, E. (1994). Incidencia de factores sociofísicos sobre el desarrollo progresivo en conjuntos de lotes con servicio. Boletín INVI, 9(21), 17-53. Retrieved on November 10, 2019 from http://repositorio.uchile.cl/handle/2250/118173

Sreejesh, S., \& Mohapatra, S. (2013). Mixed method research design: an application in consumer-brand relationships (CBR): Springer Science \& Business Media, Springer International Publishing. https://doi.org/10.1007/978-3-31902687-9

Tipple, A. G., \& Ameen, M. S. (1999). User initiated extensionc activity in Bangladesh: building slums or area improvement? Environment and Urbanization, 11(1), 165-184.

Turner, J. F., \& Fichter, R. (1972). Freedom to build: dweller control of the housing process: Macmillan.

UN-Desa. (2014). World urbanization prospects: The 2014 revision, highlights. United Nations, Department of Economic and Social Affairs (UN-DESA), Population Division. United Nations publication. New York. Retrieved on July 10, 2017 from https://esa. un. org/unpd/wup/Publications/Files/WUP2014-Highlights.pdf 
UN-Habitat. (2001). The State of the World's Cities Report 2001 (Vol. 17). United Nations Human Settlements Programme, UN-Habitat Nairobi, Kenya.

UN-Habitat. (2011). Affordable land and housing in Latin America and The Caribbean. United Nations Human Settlements Programme, UN-Habitat, Adequate Housing Series (Vol. 1). Nairobi, Kenya. Retrieved on 20 April 2019 from https://unhabitat.org/affordable-land-and-housing-in-latin-america-and-the-caribbean-2

UN-Habitat. (2016). New Urban agenda. Quito declaration on sustainable cities and human settlements for all. United Nations Human Settlements Programme, UN-Habitat Quito, Ecuador. Retrieved on 10 February 2019 from https://habitat3.org/wp-content/uploads/NUA-English.pdf

UN-Habitat, UNSD, \& Cities Alliance. (2002). Expert Group Meeting on Urban Indicators: Secure Tenure, Slums and Global Sample of Cities. United Nations Human Settlements Programme, UN-Habitat, United Nations Statistics Division \& Cities Alliance. Nairobi, Kenya. Retrieved on February 15, 2018 from https://www.citiesalliance.org/sites/default/files/expert-group-meeting-urban-indicators\%5B1\%5D.pdf

Vallejos, P. (2012). Incendio afectó al sector de la ex Quinta Monroy en Iquique [Fire affected the former Quinta Monroy]. La Estrella de Iquique,. Retrieved on March 10, 2018 from http://www.soychile.cl/Iquique/Sociedad/2012/02/19/72811/Incendio-afecto-al-sector-de-la-ex-Quinta-Monroyen-Iquique.aspx

Vergara, L. M., Gruis, V., \& van der Flier, K. (2019). Understanding housing management by low-income homeowners: Technical, organisational and sociocultural challenges in Chilean condominium housing. Buildings, 9(3), 65. https://doi.org/10.3390/buildings9030065

Vergara Perucich, F., \& Boano, C. (2016). Bajo escasez ¿Media casa basta? Reflexiones sobre el Pritzker de Alejandro Aravena \{In scarcity Is half-the-house enough? Reflections on the Alejandro Aravena's Pritzker\}. Revista de Arquitectura, 21(31), 37-46. https://doi.org/10.5354/0719-5427.2016.42516

WHO. (2010). International Workshop on Housing, Health and Climate Change: Developing guidance for health protection in the built environment mitigation and adaptation responses. In Meeting Report, Geneva, October (p. 1315): World Health Organization.

World Bank. (2014). Population living in slums (\% of urban population) - Latin America \& Caribbean. Retrieved on 10 November 2019 from

https://data.worldbank.org/indicator/EN.POP.SLUM.UR.ZS?end=2014\&locations=ZJ\&start=1990\&view=chart

Editor: Rodrigo Firmino

Received on 02 jan. 2020

Approved on 22 set. 2020 